\title{
Phytochemical characterization of the mushroom Agaricus bisporus and assessment of its nutritional ability in the place of fishmeal for survival and growth of the freshwater prawn Macrobrachium rosenbergii post-larvae
}

\author{
Eswari S, Saravana Bhavan P*, Kalpana R, Dharani C, Manjula T, Sarumathi K and Rajkumar G \\ Department of Zoology, Bharathiar University, Coimbatore-641046, India
}

\begin{abstract}
Prawn is nutritious delicacy to mankind. Fishmeal is a chief value protein ingredient in prawn feed, which is a depleting resource. The present study was conducted to assess whether edible Mushroom, Agaricus bisporus can partially be replaced the fishmeal to promote the growth of the freshwater prawn, Macrobrachium rosenbergii post-larvae (PL). In the methanolic extract of $A$. bisporus, the presence of terpenoids, flavonoids, polyphenols, saponins and cardiac glycosides were qualitatively detected. In the petrolium etheric extract of $A$. bisporus, the presence of alkaloids, terpenoids, tannins, polyphenols, cardiac glycosides and quinines were qualitatively detected. A. bisporus, containing 14 secondary phytochemicals, of which 9 compounds \{Dodecanoic acid; Tetradecanoic acid; 2-Pentadecanone, 6, 10, 14-trimethyl; Hexadecanoic acid, methyl ester; 4-(6, 6-Dimethyl-2-methylenecyclohex-3-enylidene) pentan-2-ol; Tetradecanoic acid; Neophytadiene; Hexadecanoic acid; 9, 12, $15-$ Octadecatrienoic acid, ethyl ester, $(Z, Z, Z)$ - $\}$ having bioactive properties. Isonitric diets were prepared by replacement of the fishmeal $(25 \%, 50 \%, 75 \%$ and $100 \%)$ with $A$. bisporus powder. Diet prepared without replacement of fishmeal was served as control. These diets were fed to $M$. rosenbergii PL ( $1.00 \pm 0.20 \mathrm{~cm}$ in length and $0.07 \pm 0.02 \mathrm{~g}$ in weight) for 90 days, and $75 \%$ fishmeal replaced diet produced significant elevations in survival and growth rates, muscle total protein, amino acid, carbohydrate, lipid and ash contents, profiles of proteins, amino acids and fatty acids and activities of protease, amylase and lipase when compared with control. Thus, it is recommended that up to $75 \%$ of fishmeal can be replaced with $A$. bisporus for sustainable maintenance of $M$. rosenbergii seeds in the nursery. This would offer better nutrition and employment opportunity.
\end{abstract}

\section{Introduction}

The giant freshwater prawn Macrobrachium rosenbergii is commercially cultured in India and other south Asian countries as it is nutritious delicacy for mankind and have high market price with good export value [1]. This seafood yields quality protein for averting malnutrition. Although its culture is profitable, there are some constraints in the grow-out phase [2]. The availability of quality seeds and feeds are major constrains. The feed price plays a vital role in overall operational cost. Thus, feed formulations with locally available low cost agricultural, animal husbandry and industrial by-products are in practices $[3,4]$. Fishmeal is one of the chief valued ingredients for protein source in artificial feed formulation. Its stock is depleting day by day, whereas the cost is on the reverse. Therefore, there is an urgent need for finding out some alternatives.

The fishmeal can efficiently be replaced by alternative protein sources such as soybean protein and poultry by-products [5-7]. Mushroom by-product also considered as one of the alternative sources for replacing the fishmeal protein in fish. In fact, mushroom stalk itself contained a rich source of protein, polysaccharide and antioxidant. The stalk of mushroom, Pleurotus sajor caju when given as feed to replace fishmeal protein yields good growth in the fingerlings of Nile tilapia, Oreochromis niloticus [8]. Mushroom meal is more suitable and acceptable ingredient in the fish feed than fishmeal for the better growth of fingerlings of Labeo rohita and Hemigrammus caudovittatus [9]. According to Zhang et al. [10], when the dietary fishmeal (up to
$80 \%$ ) was replaced with fermented mushroom bran hydrolysate, the weight gain ratio, protein efficiency ratio, digestive enzyme activity, and antioxidant capacity in the Crucian carp, Carassius carassius were significantly improved. No study is available with mushroom as an ingredient in prawn feed.

Mushrooms have been viewed as gourmet food over the globe for their unique taste with inconspicuous flavor and useful proteins, low total fat with the high extent of polyunsaturated fatty acids (PUFA), carbohydrates, fibers, minerals and vitamins, thiamine (B1), riboflavin (B2), cyanocobalamine (B12), ascorbic acid (C), Vit-D, and Vit-E [11-15]. Mushrooms have a low glycemic record and high mannitol which is particularly valuable for diabetics, low sodium (Na) concentration which is valuable for hypertensive patients and a high amount of potassium $(\mathrm{K})$ and phosphorus $(\mathrm{P})$ which is an imperative orthomolecule. Various biologically active metabolites including glycoproteins, hydrolytic and oxidative compounds, phenolics and lipids were exerted immune modulation, enhancing nonspecific defense and increase disease resistance in aquaculture animals [16-19].

${ }^{\star}$ Correspondence to: P Saravana Bhavan, Department of Zoology, Bharathiar University, Coimbatore- 641046, Tamil Nadu, India, Tel: +914222428495/ +919842498138; E-mail: bhavan@buc.edu.in

Key words: Agaricus bisporus, Macrobrachium rosenbergii, survival, growth, protein, amino acid, fatty acid, digestive enzymes

Received: May 27, 2018; Accepted: June 13, 2019; Published: June 17, 2019 
Eswari S (2019) Phytochemical characterization of the mushroom Agaricus bisporus and assessment of its nutritional ability in the place of fishmeal for survival and growth of the freshwater prawn Macrobrachium rosenbergii post-larvae

Button mushroom contains moisture (90-93\%), good quality protein (28-42.5\%) with lysine and tryptophan that are normally lacking in cereals, fibre (8.3-16.2\%), ash (9.4-14.5\%), carbohydrates $(59.4 \%)$ with glycogen, chitin, and hemicellulose instead of starch, a very low fat $(3.1 \%)$ with rich in linoleic acid, and cholesterol is absent and in its place ergo-sterol is present. $100 \mathrm{~g}$ (dry wt.) button mushroom also contains several minerals including, calcium $(71.0 \mathrm{mg})$, phosphorous (912 mg), sodium (106 mg), iron (8.8 mg), and potassium (2850 mg). Mushrooms are fairly good source of vitamin $\mathrm{C}$ and vitamin $\mathrm{B}$ complex, particularly thiamine, riboflavin, niacin, biotin and pantothenic acid. Mushrooms also contains folic acid and vitamin B12 which are absent in most vegetables [20].

In India, Agaricus bisporus is the most popular variety which fetches high price [21]. It is a good source of trace elements like sodium, potassium, and phosphorus, conjugataed linoleic acid and antioxidants [22]. A. bisporus extracts can be potentially applied in Alzheimer's disease since it has acetylcholinesterase and butyrylcholinesterase inhibition activity [23]. The extracts of $A$. bisporus and its bioactive compounds are used as antioxidant, anti-cancer and anti-inflammatory against coronary heart diseases, diabetes mellitus, bacterial and fungal infections, and disorders of human immune system [24-30]. A. bisporus contain three main polysaccharides $\alpha$-glucan, $\beta$-glucan and galactomannan [31], and fatty acids mainly linoleic, palmitic and stearic acids [32].

In above views, the present study was conducted by partially replacing the fishmeal with edible mushroom, A. bisporus. First, its proximate biochemical composition was assessed, and then its survival and growth promoting potential has been evaluated on the late aged post-larvae (PL) of $M$. rosenbergii by replacing the fishmeal in its artificial diet. Contents of basic biochemical constituents such as total protein, amino acid, carbohydrate and lipid, profiles of protein, amino acids and fatty acids, and activities of digestive enzymes such as protease, amylase and lipase were studied in this economically important prawn.

\section{Materials and methods}

\section{Procurement of the mushroom A. bisporus}

The mushroom, A. bisporus was procured from JPR Agro Farms, Porthiyada, the Nilgiris, Tamil Nadu, India (Figure 1). The species was authenticated by Dr. G. V. S. Murthy, Scientist 'G', Southern Regional Center, Botanical Survey of India (BSI), Coimbatore, India. The procured mushroom was cleaned by rubbing, scraping and brushing to

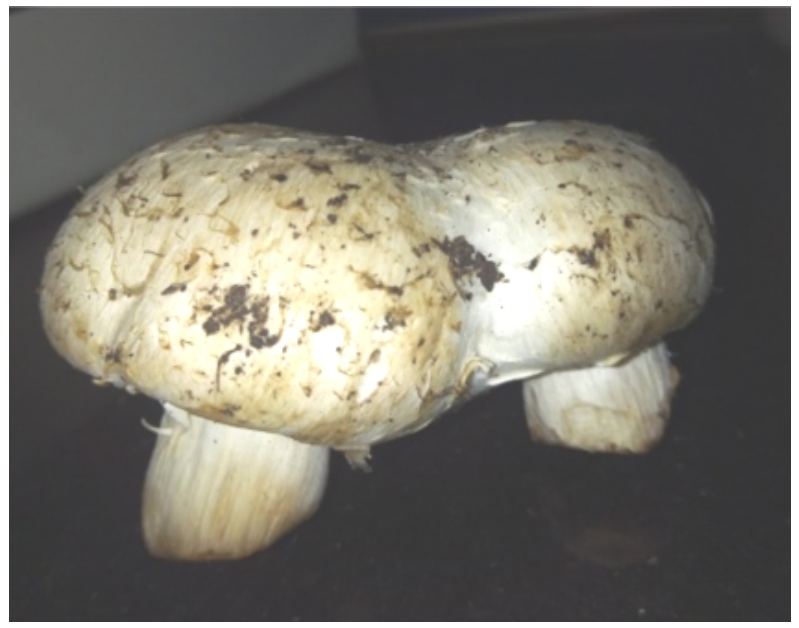

Figure 1. The mushroom, Agaricus bisporus remove foreign matters. They were washed with freshwater, blotted, and cut into small pieces of around 2 to $3 \mathrm{~cm}$ across. They were air-dried under shade for 15-21 days. Then they were ground into a fine powder and stored in sterilized containers.

\section{Preparation of solvent extracts of $\boldsymbol{A}$. bisporus}

The powdered whole plant sample of A. bisporus (50 g) was packed in Whatmann No. 1 filter paper and put into soxhlet apparatus. The extracts were successively soaked with $300 \mathrm{ml}(1: 6 \mathrm{w} / \mathrm{v})$ of non-polar solvent, petroleum ether (99.98\% purity, SRL Pvt. Ltd. India), and a polar solvent, methanol (99.9\% purity, Changshu Yangyuan Chemicals, China) individually and sequentially extracted for 6-9 h each (30 to 36 cycle). Repeated extraction was done until a clear colorless solution was obtained. The extracts were filtered by using double layered muslin cloth and concentrated at $40-50^{\circ} \mathrm{C}$ using rotary vacuum evaporator (ROTAVAP). The extracts obtained were vacuum-dried under $40^{\circ} \mathrm{C}$ and used for further investigation. The extracts obtained were appeared as dark green, gummy solid.

\section{Qualitative analysis of primary phytochemical substances}

The extracts were subjected to detection of the presence of primary phyto-molecules, such as alkaloids, terpenoids, flavonoids, tannins, polyphenols, saponins, and cardiac glycosides using the standard qualitative procedures [33].

\section{Gas Chromatography-Mass Spectrum (GC-MS) analysis for secondary phytochemical compounds}

The petroleum etheric and methanolic extracts of A. bisporus were subjected to GC-MS analysis (Thermo GC-trace ultra ver-5.0; Thermo MS-DSQ-II; ZB 5-MS capillary standard non-polar column (30 mts, $0.25 \mathrm{~mm}$ id, $0.25 \mu \mathrm{m}$ film) for identification of different phytochemical compounds at South India Textile Research Association (SITRA), Coimbatore, Tamil Nadu, India. The relative percentage constituent was expressed as percentage with peak area normalization. Peaks resolved with relative abundance of 0-100 were considered as major compounds. To show the minor peaks, the chromatogram was magnified. Identification of various components present in these extracts were assigned by the comparison of their retention indices and mass spectra fragmentation patterns with those stored on the computer library and also with published literatures. National Institute Standard and Technology (NIST4) and WILEY9 [34] on-line library source was also used for matching the identified components.

\section{Analysis of the proximate composition of $A$. bisporus}

A. bisporus powder was subjected to proximate composition analysis following the methodology of Castell and Tiews [35] as given in AOAC [36], and the values are presented in Table 1.

\section{Diet preparation with $A$. bisporus powder}

Diets were formulated with the following branded feed basal ingredients (BI). The fish meal, groundnut oilcake and soybean meal as protein sources, wheat bran as a carbohydrate source, sunflower oil as lipid source, and tapioca flour and egg albumin were used as binding agents. The fishmeal, groundnut oilcake, soybean meal, wheat bran, and tapioca flour were thoroughly mixed, dough was prepared with sterilized water, then it was steam cooked and cooled at room temperature. Then the Sunflower oil and egg albumin were added to the dough and mixed well. A. bisporus powder was incorporated with the dough of BI at four different concentrations, $25 \%, 50 \%, 75 \%$, and $100 \%$ by replacing the right quantity of fishmeal, and in order to prepare iso-nitric diets, 
Eswari S (2019) Phytochemical characterization of the mushroom Agaricus bisporus and assessment of its nutritional ability in the place of fishmeal for survival and growth of the freshwater prawn Macrobrachium rosenbergii post-larvae

the protein level was maintained by adjusting the groundnut oilcake and soybean meal (Table 2). Sterilized water was adequately added for maintaining the dough in moist and paste form. Then it was pelletized in a manual pelletizer (Kolkata, India) fixed with $3 \mathrm{~mm}$ diameter mesh. The pellets were dried in a thermostatic oven (M/s Modern Industrial, Mumbai, India) at $40^{\circ} \mathrm{C}$ until they reached a constant weight and stored in airtight jars at room temperature. The pelletized feeds were subjected to proximate composition analyses (AOAC) [36] and the results are also presented in Table 2.

\section{Procurement and acclimation of $M$. rosenbergii $\mathrm{PL}$}

The post-larvae (PL-15) of the freshwater prawn, M. rosenbergii $(1.00 \pm 0.20 \mathrm{~cm}$ and $0.07 \pm 0.02 \mathrm{~g})$ length and weight respectively) were procured from the Nursery pond at Kanathur, Chennai, Tamil Nadu, India. They were transported to the laboratory in polythene bags filled with oxygenated water. The prawns were acclimatized to ambient laboratory conditions for 2 weeks in large cement tank $(1000 \mathrm{~L})$ with groundwater (Temperature, $23 \pm 1.0^{\circ} \mathrm{C} ; \mathrm{pH}, 6.8 \pm 0.20$; total dissolved solids (TDS), $0.94 \pm 0.06 \mathrm{~g} \mathrm{~L}^{-1}$; dissolved oxygen (DO), $6.40 \pm 0.10 \mathrm{mg}$ $\mathrm{L}^{-1}$; salinity, $0.59 \pm 0.02 \mathrm{mg} \mathrm{L}^{-1}$; biochemical oxygen demand (BOD), $31.10 \pm 2.82 \mathrm{mg} \mathrm{L}^{-1}$; chemical oxygen demand (COD), $108.58 \pm 5.41 \mathrm{mg}$ $\mathrm{L}^{-1}$; ammonia $\left.0.027 \pm 0.004 \mathrm{mg} \mathrm{L}^{-1}\right)$, APHA [37]. During acclimatization, the prawns were fed with boiled egg albumin and artificially prepared feed of our own laboratory feed. More than $50 \%$ of tank water was routinely changed every day in order to maintain a healthy water environment and aeration was also provided. The unfed feed, feces, moult, and dead prawns if any were removed by siphoning without disturbing the prawns.

\section{Feeding trial}

M. rosenbergii (PL-30) $(1.30 \pm 0.11 \mathrm{~cm}$ in length and $0.12 \pm 0.02 \mathrm{~g}$ in weight) was starved for $24 \mathrm{~h}$ before commencing the feeding trial (Figure 2). Five groups, each with $30 \mathrm{PL}$ were maintained in $30 \mathrm{~L}$ plastic tanks under a triplicate experimental set-up. One group served as control and fed with feed formulated without incorporation of $A$. bisporus and the other four groups were fed with experimental feeds prepared by incorporation of $A$. bisporus (at $25 \%, 50 \%, 75 \%$, and $100 \%$ respectively by replacing the right quantum of fishmeal). The feed was allocated to the prawns for two times a day (7:00 am and 7:00 pm) at $10 \%$ of body weight. The experiment was extended for a period

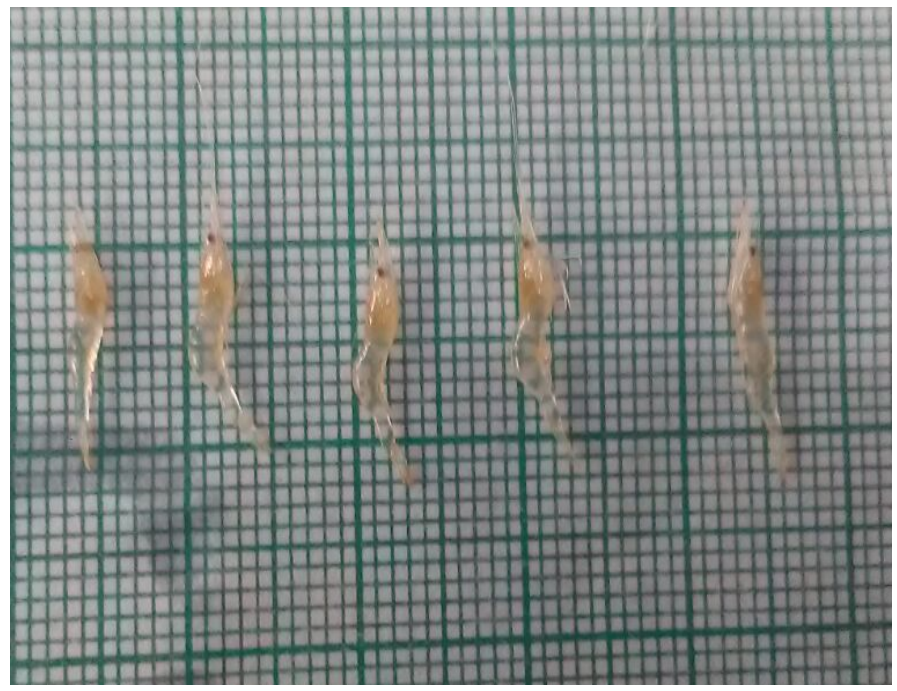

Figure 2. M. rosenbergii post-larvae at initial stage of the feeding trial of 90 days, by this time it reached the juvenile stage. The unfed feed, feces, and moult (if any) were collected on a daily basis by siphoning method causing minimum disturbance to the prawns during renewal of the water medium. For morphometric and nutritional analysis, 10 prawns from each group were randomly measured and the mean was considered as a single value (mean of 10 individual measurements $=$ one observation), and three such measurements were made to fulfill the triplicate analysis.

\section{Calculation of survival and growth parameters}

On the $90^{\text {th }}$ day of feeding trial, the growth parameters, such as survival rate (SR), length gain (LG), weight gain (WG), specific growth rate (SGR) and food conversion rate (FCR) were determined by adopting the formulae of Tekinay and Davies [38].

i. Survival $(\%)=$ Total No. of live animals/Total No. of initial animals $\times 100$

ii. Weight gain $(\mathrm{g})=$ Final weight $(\mathrm{g})$ - Initial weight $(\mathrm{g})$

iii. Specific growth rate $(\%)=\log \mathrm{W}_{2}-\log \mathrm{W}_{1} / \mathrm{t} \times 100$

Where, $\mathrm{W}_{1} \& \mathrm{~W}_{2}=$ Initial and final weight respectively (g), and $\mathrm{t}=$ Total number of experimental days

iv. Food conversion ratio $(\mathrm{g})=$ Total feed intake $(\mathrm{g}) /$ Total weight gain of the prawn $(\mathrm{g})$

v. Protein efficiency ratio $(\mathrm{g})=$ Total weight gain of $\mathrm{PL}(\mathrm{g}) /$ Total protein consumed (g)

\section{Estimations of basic biochemical constituents}

The concentrations of total protein, amino acid and carbohydrate in experimental PL were estimated by adopting the methodology of Lowry et al. [39], Moore and Stein [40] and Roe [41], respectively. The total lipid was extracted by Folch et al. [42] gravimetric method, and estimated by Barnes and Blackstock [43] spectrophotometric method. The contents of ash and moisture were analyzed by following AOAC [36] methodology.

\section{Assays of digestive enzymes activities}

Activities of digestive enzymes (protease, amylase and lipase) were assayed at $90^{\text {th }}$ day of feeding trial. The digestive tract of three prawns from each replicate were carefully dissected out and homogenized in ice-cold distilled water and centrifuged at $9000 \mathrm{~g}$ under $4^{\circ} \mathrm{C}$ for 20 min. The supernatant was used as a source of crude enzyme. Total protease activity was determined by casein-hydrolysis method of Furne et al. [44], where one unit of enzyme activity represented the amount of enzyme required to liberate $1 \mu \mathrm{g}$ of tyrosine per minute. Amylase activity was determined according to Bernfeld [45], the specific activity of amylase was calculated as milligrams of maltose liberated per gram of starch per hour $(\mathrm{mg} / \mathrm{g} / \mathrm{h})$. Lipase activity was assayed by the method of Furne et al. [44], one unit of lipase activity was defined as the amount of free fatty acid released from triacylglycerol per unit time.

\section{Analysis of protein profile}

SDS-PAGE profile of the muscle samples of prawns fed with control and $75 \%$ of fishmeal replaced with A. bisporus (the best concentration) diets were performed. The muscle tissue sample was first defrosted in phosphate buffer (137 mM NaCl, $2.7 \mathrm{mM} \mathrm{KCl}, 10 \mathrm{mM} \mathrm{Na} 2 \mathrm{HPO} 4$ and $2 \mathrm{mM} \mathrm{KH} 2 \mathrm{PO} 4, \mathrm{pH}-7.4$ ), homogenized under ice-cold condition and centrifuged at $1500 \mathrm{rpm}$ under $4^{\circ} \mathrm{C}$ for $5 \mathrm{~min}$. The soluble protein content in the supernatant was determined Lowry et al. [39]. SDS-PAGE 
Eswari S (2019) Phytochemical characterization of the mushroom Agaricus bisporus and assessment of its nutritional ability in the place of fishmeal for survival and growth of the freshwater prawn Macrobrachium rosenbergii post-larvae

was performed on vertical slab gel with $4 \%$ stacking and $10 \%$ separating gels Laemmli [46] along with protein markers ( $\beta$-galactosidase-116 $\mathrm{kDa}$, bovine serum albumin-66 $\mathrm{kDa}$, ovalbumin- $45 \mathrm{kDa}$, carbonic anhydrase- $29 \mathrm{kDa}$, soybean trypsin inhibitor- $20 \mathrm{kDa}$ and lysozyme-14 $\mathrm{kDa}$ ) of Medox-Biotech Pvt. Ltd., Chennai, India. The polypeptides banding patterns between control and test prawns were compared by using the information on apparent molecular masses of bands and their intensities.

\section{Analysis of amino acid profile}

The profiles of amino acids in the muscle samples of prawns fed with control and $75 \%$ of fishmeal replaced with A. bisporus (the best concentration) diets were performed using High-Performance Thin Layer Chromatographic (HPTLC) method of Hess and Sherma [47]. TLC for four groups of standard amino acids: lysine, asparagine, glutamine, glutamic acid and methionine (group-I); proline, serine, cysteine, tyrosine and tryptophan (group-II); histidine, arginine, aspartic acid, threonine and leucine (group-III); and glycine, alanine, valine, isoleucine and phenylalanine (group-IV) were also performed simultaneously. The peak area of the sample was compared with standard amino acids and quantified.

\section{Analysis of fatty acid profile}

The profiles of fatty acid in the muscle samples of prawns fed with control and $75 \%$ of fishmeal replaced with A. bisporus (the best concentration) diets were performed using Gas Chromatographic (GC) method of Nichols et al. [48]. Fatty acid samples were obtained from lipid by saponification using $\mathrm{NaOH}$ dissolved in methanol- $\mathrm{H}_{2} \mathrm{O}$ mixture (hydrolysis with alkali). They were methylated into fatty acid methyl ester using methanol- $\mathrm{HCl}$ mixture. The fatty acid methyl ester was separated using hexane-anhydrous diethyl ether mixture. For the organic phase, aqueous $\mathrm{NaOH}$ was used as a base wash and the upper organic layer was separated. $2 \mu \mathrm{L}$ of the sample was injected and analyzed using Chemito 8610 Gas Chromatography, with BPX70 capillary column and flame ionization detector. Nitrogen was used as a carrier gas. Standard fatty acids were analyzed simultaneously. Based on the retention time of the standard fatty acids, each fatty acid in the unknown sample was identified. The peak areas of standard and unknown were compared and quantified

\section{Statistical analysis}

The data between control versus experiment, and between experiments were subjected to statistical analysis through one-way ANOVA and subsequent post-hoc multiple comparison with DMRT by adopting the SPSS v16. All the details of statistical analyses were given in respective tables. The $\mathrm{P}$ values less than 0.05 were considered statistically (95\%) significant.

\section{Results and discussion}

\section{Primary phytochemicals of $A$. bisporus}

The primary phytochemicals present in A. bisporus are presented in Table 3. The petroleum etheric extract of $A$. bisporus contained luxurious presence of alkaloids and tannins, moderate presence of polyphenols and quinines, and terpenoids and cardiac glycosides are poorly present. The methanolic extract of $A$. bisporus contained luxurious presence of saponins, moderate presence of terpenoids, polyphenols and cardiac glycosides, and poorly presence of flavonoids. Similar to the present study, presence of alkaloids, flavonoids, phenols, steroids, terpenoids, saponins and glycoside have been reported in methanolic extract of
A. bisporus $[49,50]$. Petroleum ether, chloroform, acetone and ethanol have also been used to screen the phytochemicals of $A$. bisporous [49]. Plant derived flavonoids, anthrax quinines, and terpenens stimulate glucose uptake and exhibit hypoglycaemic activity [51], and also known for their ability of beta cell regeneration in pancreas [52].

\section{Secondary phytochemicals of $A$. bisporous}

The GC-MS analysis of A. bisporus showed overall presence of 14 compounds, of which 9 compounds possessed bioactive properties (Table 4). The petroleum etheric extract contained 5 compounds [Benzene, 1-methyl-4-(4-morpholyl) ethenylsulfonyl; Dodecanoic acid; Tetradecanoic acid; 2-Pentadecanone, 6, 10, 14-trimethyl; Hexadecanoic acid, methyl ester] (Figure 3). Among these, except benzene, 1-methyl-4-(4-morpholyl) ethenylsulfonyl, all other compounds are possessed biological properties. The methanolic extract contained 9 compounds [Hydroxydihydroedulan; 5-hydroxy1-deutero-1,2-pentadiene; methyl 2-diazo-3-oxo-4-propylhept-6enoate; 2-Bromolauric acid; 4-(6,6-Dimethyl-2-methylenecyclohex3-enylidene) pentan-2-ol; Tetradecanoic acid; Neophytadiene; Hexadecanoic acid; 9,12,15-Octadecatrienoic acid, ethyl ester, (Z, Z, $Z$ )] (Figure 4). Of which 5 compounds possessed bioactive properties, they are 4-(6,6-Dimethyl-2-methylenecyclohex-3-enylidene) pentan2-ol; Tetradecanoic acid; Neophytadiene; Hexadecanoic acid; and 9,12,15-Octadecatrienoic acid, ethyl ester, (Z, Z, Z). Various factors involved in detection of phytochemical compounds, they are the

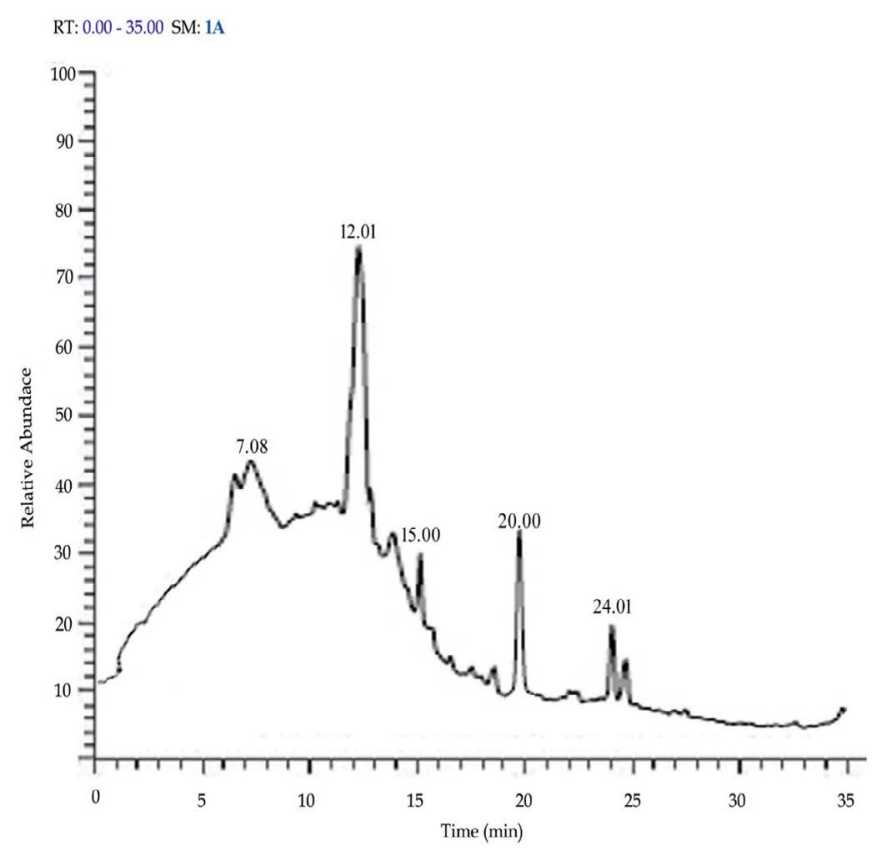

Figure 3. GC-MS peak level (magnified chromatogram) of petroleum ether extract of $A$. bisporus

\begin{tabular}{|l|l|l|l|l|l|l|}
\hline RT & Name of the compound & P & MF & MW & SI & RSI \\
\hline 7.08 & $\begin{array}{l}\text { Benzene, 1-methyl-4-(4-morpholyl) } \\
\text { ethenylsulfonyl }\end{array}$ & 14.65 & $\mathrm{C}_{13} \mathrm{H}_{17} \mathrm{NO}_{3} \mathrm{~S}$ & 267 & 332 & 395 \\
\hline 12.01 & Dodecanoic acid & 66.88 & $\mathrm{C}_{12} \mathrm{H}_{24} \mathrm{O}_{2}$ & 200 & 743 & 791 \\
\hline 15.00 & Tetradecanoic acid & 78.47 & $\mathrm{C}_{14} \mathrm{H}_{28} \mathrm{O}_{2}$ & 228 & 813 & 888 \\
\hline 20.00 & 2-Pentadecanone, 6,10,14-trimethyl & 60.40 & $\mathrm{C}_{18} \mathrm{H}_{36} \mathrm{O}$ & 268 & 686 & 717 \\
\hline 24.01 & Hexadecanoic acid, methyl ester & 57.63 & $\mathrm{C}_{17} \mathrm{H}_{34} \mathrm{O}_{2}$ & 270 & 868 & 891 \\
\hline
\end{tabular}

RT: Retention time; P: Probability; MF: Molecular formula; MW: Molecular weight; SI Similar index; RSI: Reverse similar index 
Eswari S (2019) Phytochemical characterization of the mushroom Agaricus bisporus and assessment of its nutritional ability in the place of fishmeal for survival and growth of the freshwater prawn Macrobrachium rosenbergii post-larvae

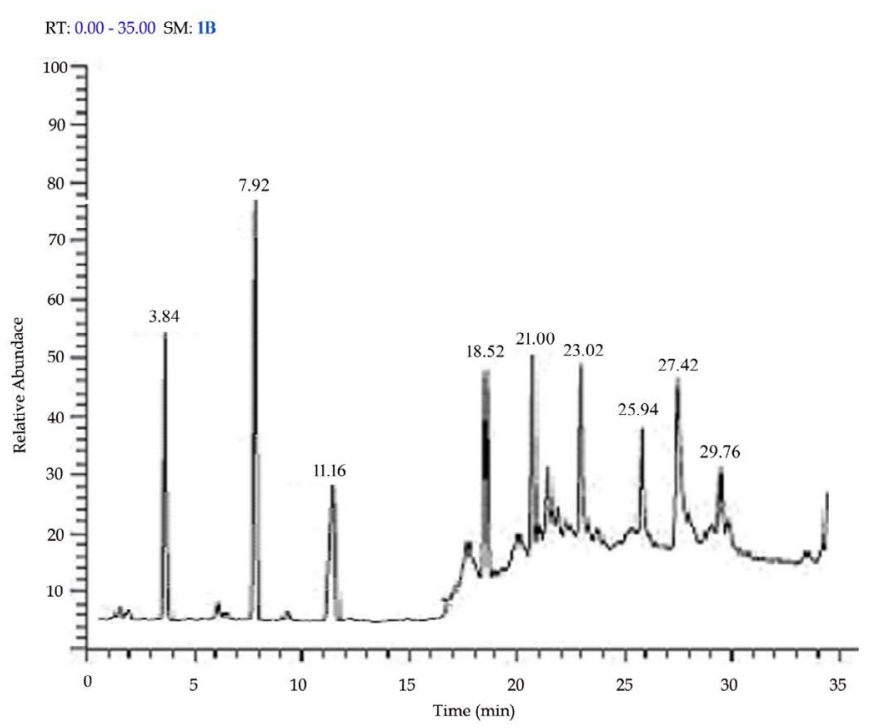

Figure 4. GC-MS peak level (magnified chromatogram) of methanolic extract of $A$. bisporus

\begin{tabular}{|c|c|c|c|c|c|c|}
\hline RT & Name of the compound & $\mathbf{P}$ & MF & MW & SI & RSI \\
\hline 3.84 & Hydroxydihydroedulan & 7.54 & $\mathrm{C}_{13} \mathrm{H}_{22} \mathrm{O}_{2}$ & 210 & 344 & 730 \\
\hline 7.92 & 5-hydroxy-1-deutero-1,2-pentadiene & 16.28 & $\mathrm{C}_{5} \mathrm{H}_{7} \mathrm{DO}$ & 84 & 636 & 858 \\
\hline 11.16 & $\begin{array}{l}\text { methyl 2-diazo-3-oxo-4-propylhept- } \\
\text { 6-enoate }\end{array}$ & 53.94 & $\mathrm{C}_{11} \mathrm{H}_{16} \mathrm{~N}_{2} \mathrm{O}_{3}$ & 224 & 413 & 599 \\
\hline 18.52 & 2-Bromolauric acid & 3.68 & $\mathrm{C}_{12} \mathrm{H}_{23} \mathrm{BrO}_{2}$ & 278 & 383 & 431 \\
\hline 21.00 & $\begin{array}{l}\text { 4-(6,6-Dimethyl-2- } \\
\text { methylenecyclohex-3-enylidene) } \\
\text { pentan-2-ol }\end{array}$ & 7.56 & $\mathrm{C}_{14} \mathrm{H}_{22} \mathrm{O}$ & 206 & 626 & 652 \\
\hline 23.02 & Tetradecanoic acid & 64.87 & $\mathrm{C}_{14} \mathrm{H}_{28} \mathrm{O}_{2}$ & 228 & 778 & 882 \\
\hline 25.94 & Neophytadiene & 25.23 & $\mathrm{C}_{20} \mathrm{H}_{38}$ & 278 & 829 & 887 \\
\hline 27.42 & Hexadecanoic acid & 75.43 & $\mathrm{C}_{16} \mathrm{H}_{32} \mathrm{O}_{2}$ & 256 & 855 & 865 \\
\hline 29.76 & $\begin{array}{l}\text { 9,12,15-Octadecatrienoic acid, ethyl } \\
\text { ester, (Z,Z,Z)- }\end{array}$ & 14.04 & $\mathrm{C}_{20} \mathrm{H}_{34} \mathrm{O}_{2}$ & 306 & 747 & 766 \\
\hline
\end{tabular}

RT: Retention time; P: Probability; MF: Molecular formula; MW: Molecular weight; SI: Similar index; RSI: Reverse similar index

presence of detectable quantity of a particular compound, soil type, soil nutrients and climatic conditions under which the plant was grown, and age of the plant [53-64].

\section{Proximate composition of $A$. bisporus and fishmeal replaced diets}

A. bisporus contained $31.46 \%$ of crude protein, $12.43 \%$ of crude fibre, $4.14 \%$ of crude fat, $11.34 \%$ of total ash, $11.29 \%$ of moisture, $1.28 \%$ of sand and silica, $0.50 \%$ of calcium, $1.07 \%$ of phosphorus and $1.36 \%$ of salt with $3840 \mathrm{kcal} / \mathrm{kg}$ of gross energy (Table 1). The total organic matters present in the isonitric basal (control) and experimental diets contained $42.62-42.86 \%$ of crude protein, $4.36-4.52 \%$ of crude fat (etheric extract), $1.18-1.29 \%$ of crude fibre, $7.57-7.72 \%$ of total ash, 8.87-9.12\% of moisture and 34.74-39.73\% total carbohydrate (nitrogen free extract) with $4367-4386$ ( kcal/kg) gross energy (Table 2). The formulated feeds satisfied the required proximate composition for freshwater prawns $(30-40 \%$ crude protein, $25-35 \%$ carbohydrate and 3-7\% lipid) prescribed by Swamy [65] and Mitra [3].

Protein is the major constituent of prawn feed as larvae and juveniles have greater requirement than adults for growth and metabolism [66]. Carbohydrates are the most economical and inexpensive source of energy. It together with proteins and lipids form a dietary source of energy and are required to synthesis of glycogen, chitin, steroid, and fatty acids [67,68]. Actually, dietary protein supplies amino acids required to build body tissues, essential for growth and production of hormones, antibodies, enzymes, etc. [66].

Survival, growth, contents of basic biochemical constituents and activities of digestive enzymes, and profiles of amino acid and fatty acid in fishmeal replaced diets fed prawns

The morphometric parameters (length and weight gains), nutritional indices (survival rate, specific growth rate and protein efficiency ratio), concentrations of basic biochemical constituents (total protein, carbohydrate, lipid, amino acid and ash) and activity of digestive enzymes (protease, amylase and lipase) were found to be gradually and significantly increased $(P<0.05)$ from $25 \%$ to $75 \%$ fishmeal replaced diets fed prawns when compared with control, whereas the $100 \%$ fishmeal replaced diet showed a decreasing trend when compared to that of other experimental diets (Table 5) (Figure 5). The reverse trend in FCR was found, which represented the quality of diets prepared.

Table 1. Proximate composition of the mushroom A. bisporus

\begin{tabular}{|l|l|}
\hline Parameters & $\begin{array}{l}\text { Proximate } \\
\text { composition } \\
\text { (\%) of } \text { A. bisporus }\end{array}$ \\
\hline Moisture & 11.29 \\
\hline Crude protein & 31.46 \\
\hline Crude fibre & 12.43 \\
\hline Ether extract & 4.14 \\
\hline Total Ash & 11.34 \\
\hline Sand and silica & 1.28 \\
\hline Calcium & 0.50 \\
\hline Phosphorus & 1.07 \\
\hline Salt & 1.36 \\
\hline Gross energy & $3840 \mathrm{kcal} / \mathrm{kg}$ \\
\hline
\end{tabular}

Table 2. Ingredients used to formulate iso-nitric diets, and proximate composition of fishmeal replaced diets with $A$. bisporus

\begin{tabular}{|c|c|c|c|c|c|}
\hline \multirow{2}{*}{$\begin{array}{l}\text { Basal ingredients } \\
\text { (g) }\end{array}$} & \multirow[t]{2}{*}{ Control } & \multicolumn{4}{|c|}{$\begin{array}{l}\text { Fishmeal replaced } \\
\text { diets with } A \text {. bisporus }\end{array}$} \\
\hline & & $25 \%$ & $50 \%$ & $75 \%$ & $100 \%$ \\
\hline Fish meal & 25 & 18.75 & 12.5 & 6.25 & 0 \\
\hline Groundnut oil cake & 25 & 29 & 31 & 34 & 35 \\
\hline Soybean meal & 25 & 29 & 31 & 34 & 35 \\
\hline Wheat bran & 10 & 10 & 10 & 10 & 10 \\
\hline Egg albumin & 7 & 7 & 7 & 7 & 7 \\
\hline Tapioca flour & 5 & 5 & 5 & 5 & 5 \\
\hline Sunflower oil & 2 & 2 & 2 & 2 & 2 \\
\hline Vitamin mix & 1 & 1 & 1 & 1 & 1 \\
\hline A. bisporus & 0 & 6.25 & 12.5 & 18.75 & 25 \\
\hline Total & 100 & 108 & 112 & 118 & 120 \\
\hline \multicolumn{6}{|c|}{ Proximate composition (\%) } \\
\hline Moisture & 8.87 & 8.91 & 8.94 & 9.01 & 9.12 \\
\hline Crude protein & 42.86 & 42.82 & 42.76 & 42.71 & 42.62 \\
\hline Crude fibre & 1.29 & 1.26 & 1.23 & 1.20 & 1.18 \\
\hline Crude fat & 4.52 & 4.48 & 4.45 & 4.41 & 4.36 \\
\hline Total Ash & 7.72 & 7.68 & 7.64 & 7.61 & 7.57 \\
\hline Total carbohydrate & 34.74 & 34.85 & 34.98 & 35.06 & 39.73 \\
\hline Gross energy $(\mathrm{kcal} / \mathrm{kg})$ & 4367 & 4375 & 4381 & 4386 & 4372 \\
\hline
\end{tabular}

"Each capsule contains, Total mg=438.5 mg; Thiamine Mononitrate IP, $10 \mathrm{mg}$; Riboflavin IP, $10 \mathrm{mg}$; Pyridoxine Hydrochloride IP, $3 \mathrm{mg}$; Vitamin B12 (as tablets 1:100) IP, $15 \mathrm{mcg}$; Niacinamide IP, $100 \mathrm{mg}$; Calcium pantothenate IP, $50 \mathrm{mg}$; Folic acid IP, $1.5 \mathrm{mg}$; Biotin USP, $100 \mathrm{mg}$; Ascorbic acid IP, $150 \mathrm{mg}$ manufactured by Pfizer. 
Eswari S (2019) Phytochemical characterization of the mushroom Agaricus bisporus and assessment of its nutritional ability in the place of fishmeal for survival and growth of the freshwater prawn Macrobrachium rosenbergii post-larvae

\section{Amino acid and fatty acid profiles of $75 \%$ fishmeal replaced diet fed prawns}

The content of all the essential (histidine, isoleucine, leucine, lysine, methionine, phenylalanine, threonine, valine, arginine, asparagines, and glycine) and non-essential (glutamic acid, proline, alanine, tyrosine, aspartic acid, cysteine, and glutamine) amino acids were found to be significantly elevated $(P<0.05)$ in $75 \%$ fishmeal replaced diet fed prawns when compared with control (Table 6). Similarly, the contents of saturated fatty acids (lauric acid, myristic acid, palmitic acid, stearic acid, and arachidic acid), monounsaturated fatty acids (palmitoleic acid, and oleic acid) and polyunsaturated fatty acids (linoleic acid, EPA and DHA) were found to be significantly increased $(P<0.05)$ in $75 \%$
Table 3. The primary phytochemicals present in A. bisporous extracts

\begin{tabular}{|c|c|c|}
\hline \multirow{2}{*}{ Phytochemicals } & \multicolumn{2}{|c|}{ Solvents used } \\
\cline { 2 - 3 } & $\begin{array}{c}\text { Petrolium ether } \\
\text { (non- polar) }\end{array}$ & $\begin{array}{c}\text { Methanol } \\
\text { (polar) }\end{array}$ \\
\hline Alkaloids & +++ & -- \\
\hline Terpenoids & + & ++ \\
\hline Flavonoids & -- & + \\
\hline Tannins & +++ & -- \\
\hline Polyphenols & ++ & ++ \\
\hline Saponins & -- & +++ \\
\hline Cardiac glycosides & + & ++ \\
\hline Quinones & ++ & -- \\
\hline
\end{tabular}

${ }^{+}$Poorly present; ${ }^{++}$Moderately present; ${ }^{++}$Luxuriantly present; --Absent

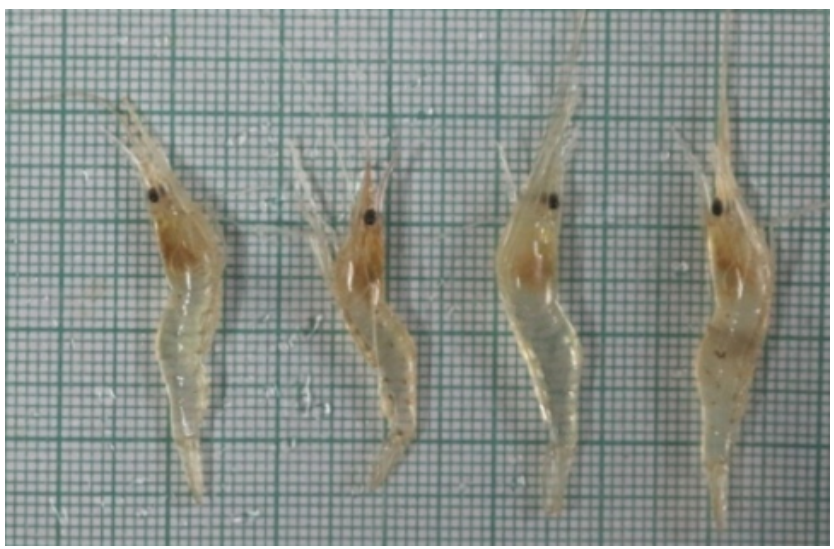

$90^{\text {th }}$ day of $M$. rosenbergii PL fed with control diet

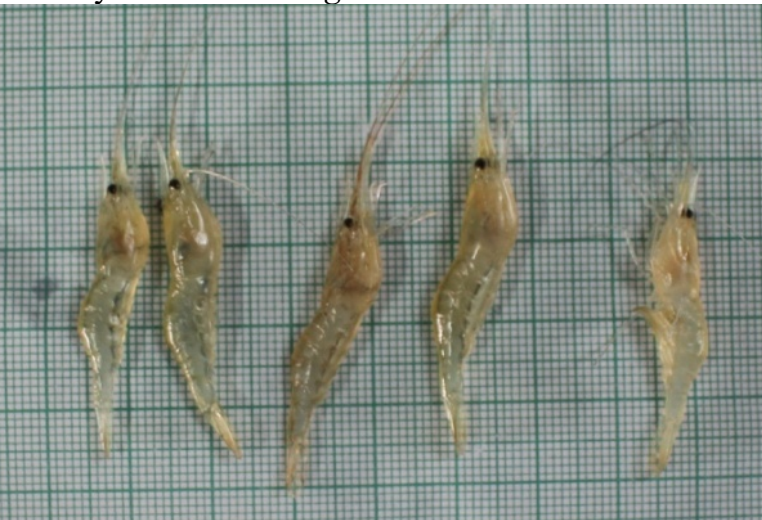

$90^{\text {th }}$ day of $M$. rosenbergii PL fed with $25 \%$ fishmeal replaced diet with $A$. bisporus

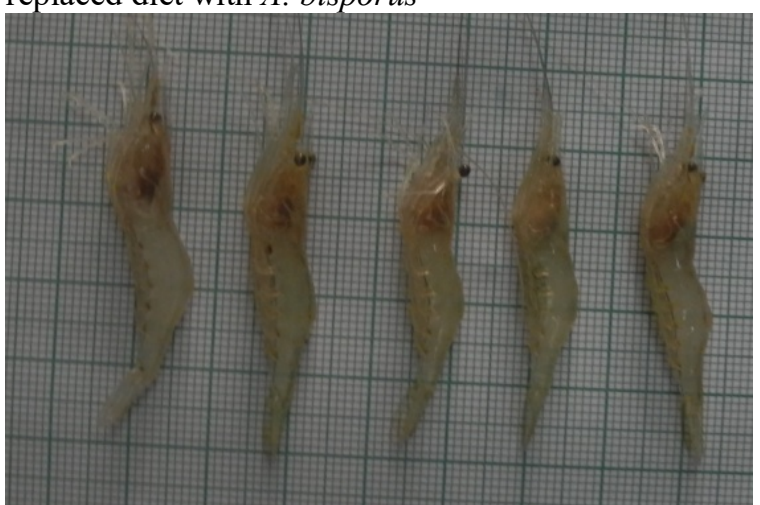

$90^{\text {th }}$ day of $M$. rosenbergii PL fed with $75 \%$ fishmeal replaced diet with $A$. bisporus

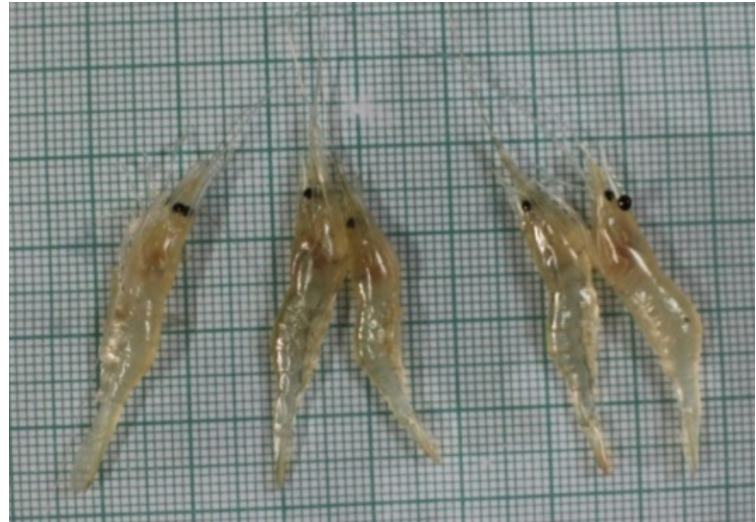

$90^{\text {th }}$ day of $M$. rosenbergii PL fed with $50 \%$ fishmeal replaced diet with $A$. bisporus

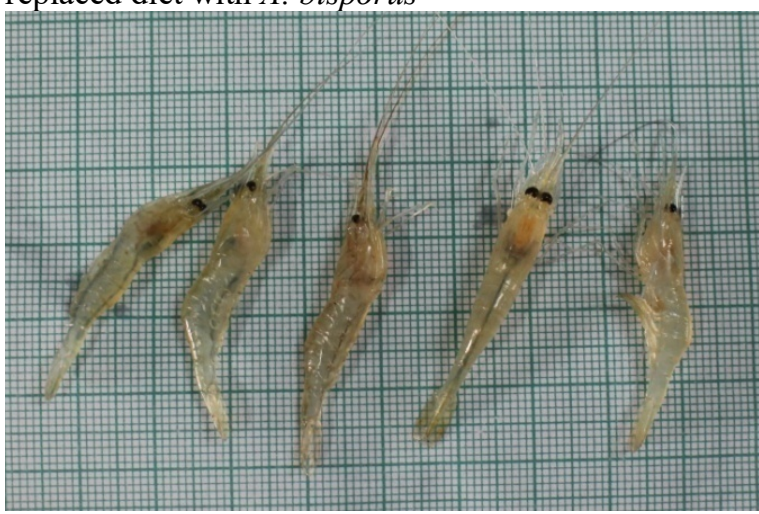

$90^{\text {th }}$ day of $M$. rosenbergii PL fed with $100 \%$

fishmeal replaced diet with $A$. bisporus

Figure 5. Fishmeal replaced diet fed $M$. rosenbergii PL with $A$. bisporus 
Eswari S (2019) Phytochemical characterization of the mushroom Agaricus bisporus and assessment of its nutritional ability in the place of fishmeal for survival and growth of the freshwater prawn Macrobracbium rosenbergii post-larvae

Table 4. Secondary phytochemical compounds identified through GC-MS in A. bisporus extracted using different solvents, and their chemical structures and formulae

\begin{tabular}{|c|c|c|c|c|c|}
\hline Sl. No. & Peak RT & Solvent used & Name of compounds & Chemical structure and molecular formula & $\begin{array}{l}\text { Biological properties } \\
\text { (by literature only) }\end{array}$ \\
\hline 1 & 3.84 & Methanol & Hydroxydihydroedulan & $\mathrm{C}_{13} \mathrm{H}_{22} \mathrm{O}_{2}$ & - \\
\hline 2 & 7.08 & petroleum ether & $\begin{array}{l}\text { Benzene, 1-methyl-4-(4-morpholyl) } \\
\text { ethenylsulfonyl }\end{array}$ & $\mathrm{C}_{13} \mathrm{H}_{17} \mathrm{NO}_{3} \mathrm{~S}$ & - \\
\hline 3 & 7.92 & Methanol & 5-hydroxy-1-deutero-1,2-pentadiene & $\mathrm{C}_{5} \mathrm{H}_{7} \mathrm{DO}$ & - \\
\hline 4 & 11.16 & Methanol & $\begin{array}{l}\text { methyl 2-diazo-3-oxo-4-propylhept-6- } \\
\text { enoate }\end{array}$ & $\mathrm{C}_{11} \mathrm{H}_{16} \mathrm{~N}_{2} \mathrm{C}$ & - \\
\hline 5 & 12.01 & petroleum ether & $\begin{array}{l}\text { Dodecanoic acid* } \\
\text { (lauric acid) }\end{array}$ & $\mathrm{C}_{12} \mathrm{H}_{24} \mathrm{O}_{2}$ & $\begin{array}{l}\text { Anti-microbial, nematicide and } \\
\text { pesticide }[54,55] \text {. }\end{array}$ \\
\hline 6 & 15.00 & petroleum ether & $\begin{array}{l}\text { Tetradecanoic acid" } \\
\text { (myristic acid) }\end{array}$ & $\mathrm{C}_{14} \mathrm{H}_{28} \mathrm{O}_{2}$ & $\begin{array}{l}\text { Antioxidant, anticancer, } \\
\text { hypercholestrolemic, } \\
\text { larvicidal repellent activity, nematicide } \\
\text { [56-58]. }\end{array}$ \\
\hline 7 & 18.52 & Methanol & 2-Bromolauric acid & $\mathrm{C}_{12} \mathrm{H}_{23} \mathrm{BrO}_{2}$ & - \\
\hline 8 & 20.00 & petroleum ether & $\begin{array}{l}\text { 2-Pentadecanone, 6,10,14-trimethyl* } \\
\text { (Hexahydrofarnesyl acetone) }\end{array}$ & $\mathrm{C}_{18} \mathrm{H}_{36} \mathrm{O}$ & $\begin{array}{l}\text { Skin creams, lotion, cosmetic products } \\
\text { [59]. }\end{array}$ \\
\hline 9 & 21.00 & Methanol & $\begin{array}{l}\text { 4-(6,6-Dimethyl-2-methylenecyclohex-3- } \\
\text { enylidene) pentan-2-ol* }\end{array}$ & $\mathrm{C}_{14} \mathrm{H}_{22} \mathrm{O}$ & Melamine, dyes [60]. \\
\hline 10 & 23.02 & Methanol & $\begin{array}{l}\text { Tetradecanoic acid* } \\
\text { (myristic acid) }\end{array}$ & $\mathrm{C}_{14} \mathrm{H}_{28} \mathrm{O}_{2}$ & $\begin{array}{l}\text { Antioxidant, anticancer, } \\
\text { hypercholestrolemic, larvicidal } \\
\text { repellent activity, and nematicide } \\
\text { [56-58]. }\end{array}$ \\
\hline 11 & 24.01 & petroleum ether & $\begin{array}{l}\text { Hexadecanoic acid, methyl ester } \\
\text { (Palmitic acid, methyl ester) }\end{array}$ & m $\mathrm{C}_{17} \mathrm{H}_{34} \mathrm{O}_{2}$ & $\begin{array}{l}\text { Antibacterial andantifungal } \\
{[61] .}\end{array}$ \\
\hline 12 & 25.94 & Methanol & $\begin{array}{l}\text { Neophytadiene" } \\
\text { (neophytadiene) }\end{array}$ & & $\begin{array}{l}\text { Antipyretic, analgesic, anti } \\
\text { inflammatory, antimicrobial and } \\
\text { antioxidant [62]. }\end{array}$ \\
\hline 13 & 27.42 & Methanol & $\begin{array}{l}\text { Hexadecanoic acid* } \\
\text { (palmitic acid) }\end{array}$ & & $\begin{array}{l}\text { Antioxidant, hypocholesterolemic, } \\
\text { nematicide, pesticide, lubricant, anti- } \\
\text { androgenic, flavor, hemolytic, and } \\
\text { 5-alpha reductase inhibitor [63]. }\end{array}$ \\
\hline 14 & 29.76 & Methanol & $\begin{array}{l}\text { 9,12,15-Octadecatrienoic acid, ethyl ester, } \\
\text { (Z,Z,Z)-* } \\
\text { (linolenic acid, ethyl ester) }\end{array}$ & $\mathrm{C}_{20} \mathrm{H}_{34} \mathrm{O}_{2}$ & Anti-cancer [64]. \\
\hline
\end{tabular}

"Compounds having bioactive properties. 
Eswari S (2019) Phytochemical characterization of the mushroom Agaricus bisporus and assessment of its nutritional ability in the place of fishmeal for survival and growth of the freshwater prawn Macrobrachium rosenbergii post-larvae

fishmeal replaced diet fed prawns when compared with control (Table 7). The elevated profiles of amino acid and fatty acid determined the high survival and growth of $M$. rosenbergii PL.

The result recorded clearly indicated the fact that $75 \%$ of fishmeal replaced diet with $A$. bisporus produced better survival and growth, contents of protein, essential amino acids, unsaturated fatty acids, and activities of protease, amylase and lipase. Therefore, replacement of fishmeal with mushroom contributes to an increase in protein assimilation and feed utilization. The improved essential amino acids involved in energy metabolism, protein synthesis, osmoregulation and neurotransmitter [69-73]. Improved survival, growth and nutritional indices, contents of protein, carbohydrate and lipid, activities of protease, amylase and lipase, and profiles of amino acid and fatty acid have been reported in $M$. rosenbergii PL fed with $50 \%$ replacement of

Table 5. Nutritional indices, basic biochemical constituents and activities of digestive enzymes of $M$. rosenbergii PL fed with fishmeal replaced diets with $A$. bisporus

\begin{tabular}{|c|c|c|c|c|c|c|}
\hline \multirow{2}{*}{\multicolumn{2}{|c|}{ Parameters }} & \multirow{3}{*}{$\begin{array}{c}\text { Control } \\
78.88 \pm 2.50^{\mathrm{d}} \\
\end{array}$} & \multicolumn{4}{|c|}{ Fishmeal replaced diets with $A$. bisporus } \\
\hline & & & \multirow{2}{*}{$\begin{array}{c}\mathbf{2 5 \%} \\
84.44 \pm 2.50^{c}\end{array}$} & \multirow{2}{*}{$\begin{array}{c}\mathbf{5 0 \%} \\
88.88 \pm 1.89^{\mathrm{b}}\end{array}$} & \multirow{2}{*}{$\begin{array}{c}\mathbf{7 5 \%} \\
93.33 \pm 1.92^{\mathrm{a}}\end{array}$} & \multirow{2}{*}{$\begin{array}{c}\mathbf{1 0 0 \%} \\
82.22 \pm 2.50^{\mathrm{c}}\end{array}$} \\
\hline \multirow{8}{*}{$\begin{array}{l}\text { Nutritional } \\
\text { indices }\end{array}$} & SR $(\%)$ & & & & & \\
\hline & Length $(\mathrm{cm})$ & $3.35 \pm 0.107^{\mathrm{e}}$ & $4.40 \pm 0.13^{\mathrm{c}}$ & $4.90 \pm 0.09^{\mathrm{b}}$ & $5.74 \pm 0.07^{\mathrm{a}}$ & $4.26 \pm 0.12^{\mathrm{d}}$ \\
\hline & LG $(\mathrm{cm})$ & $2.06 \pm 0.06^{\mathrm{e}}$ & $3.13 \pm 0.05^{\mathrm{c}}$ & $3.67 \pm 0.07^{b}$ & $4.44 \pm 0.02^{\mathrm{a}}$ & $2.91 \pm 0.06^{\mathrm{d}}$ \\
\hline & Weight $(\mathrm{g})$ & $0.95 \pm 0.07^{\mathrm{d}}$ & $1.89 \pm 0.09^{c}$ & $2.27 \pm 0.05^{\mathrm{b}}$ & $2.80 \pm 0.04^{\mathrm{a}}$ & $1.35 \pm 0.10^{\mathrm{cd}}$ \\
\hline & WG (g) & $0.83 \pm 0.03^{\mathrm{de}}$ & $1.79 \pm 0.03^{\mathrm{c}}$ & $2.17 \pm 0.05^{\mathrm{b}}$ & $2.70 \pm 0.02^{\mathrm{a}}$ & $1.24 \pm 0.03^{\mathrm{d}}$ \\
\hline & SGR (\%) & $1.02 \pm 0.06^{\mathrm{cd}}$ & $1.30 \pm 0.04^{b}$ & $1.38 \pm 0.05^{\mathrm{ab}}$ & $1.47 \pm 0.08^{\mathrm{a}}$ & $1.15 \pm 0.07^{\mathrm{c}}$ \\
\hline & FCR (g) & $0.79 \pm 0.03^{\mathrm{a}}$ & $0.70 \pm 0.01^{\mathrm{c}}$ & $0.65 \pm 0.03^{\mathrm{d}}$ & $0.61 \pm 0.02^{\mathrm{de}}$ & $0.74 \pm 0.05^{\mathrm{b}}$ \\
\hline & PER (g) & $2.95 \pm 0.11^{\mathrm{d}}$ & $3.34 \pm 0.13^{\mathrm{c}}$ & $3.60 \pm 0.17^{b}$ & $3.81 \pm 0.11^{\mathrm{a}}$ & $3.14 \pm 0.12^{\mathrm{cd}}$ \\
\hline \multirow{6}{*}{$\begin{array}{l}\text { Biochemical } \\
\text { Constituents } \\
\text { (mg/g wet wt.) }\end{array}$} & Protein & $75.92 \pm 2.32^{\mathrm{e}}$ & $87.75 \pm 2.71^{\mathrm{c}}$ & $92.4 \pm 1.52^{\mathrm{b}}$ & $109.7 \pm 2.23^{\mathrm{a}}$ & $82.36 \pm 1.96^{\mathrm{d}}$ \\
\hline & Amino acid & $25.81 \pm 1.26^{\mathrm{e}}$ & $43.93 \pm 1.50^{\mathrm{c}}$ & $57.03 \pm 1.58^{\mathrm{b}}$ & $71.35 \pm 1.17^{\mathrm{a}}$ & $34.6 \pm 0.83^{\mathrm{d}}$ \\
\hline & Carbohydrate & $17.68 \pm 0.31^{\mathrm{e}}$ & $23.22 \pm 0.73^{\mathrm{c}}$ & $27.14 \pm 0.45^{b}$ & $35.95 \pm 0.83^{\mathrm{a}}$ & $15.89 \pm 0.40^{\mathrm{d}}$ \\
\hline & Lipid & $9.24 \pm 0.24^{\mathrm{e}}$ & $19.55 \pm 0.17^{\mathrm{c}}$ & $23.45 \pm 0.33^{b}$ & $37.49 \pm 0.48^{\mathrm{a}}$ & $13.37 \pm 0.59^{d}$ \\
\hline & Moisture (\%) & $83.55 \pm 2.41^{\mathrm{a}}$ & $74.12 \pm 2.58^{\mathrm{bc}}$ & $70.14 \pm 3.27^{\mathrm{cd}}$ & $68.23 \pm 3.37^{\mathrm{d}}$ & $77.10 \pm 2.32^{\mathrm{b}}$ \\
\hline & Ash (\%) & $14.97 \pm 1.45^{\mathrm{c}}$ & $23.53 \pm 2.21^{\mathrm{ab}}$ & $24.12 \pm 1.85^{\mathrm{a}}$ & $26.43 \pm 1.89^{\mathrm{a}}$ & $20.12 \pm 2.58^{b}$ \\
\hline \multirow{3}{*}{$\begin{array}{l}\text { Digestive enzymes } \\
\text { (U/mg protein) }\end{array}$} & Protease & $3.66 \pm 1.61^{\mathrm{b}}$ & $4.47 \pm 0.15^{\mathrm{b}}$ & $4.61 \pm 0.21^{\mathrm{ab}}$ & $5.92 \pm 0.20^{\mathrm{a}}$ & $4.13 \pm 0.14^{b}$ \\
\hline & Amylase & $0.60 \pm 0.18^{\mathrm{e}}$ & $2.17 \pm 0.06^{c}$ & $2.63 \pm 0.12^{b}$ & $3.62 \pm 0.1^{\mathrm{a}}$ & $1.59 \pm 0.042^{\mathrm{d}}$ \\
\hline & Lipase* & $0.40 \pm 0.09^{\mathrm{d}}$ & $0.81 \pm 0.04^{\mathrm{bc}}$ & $0.90 \pm 0.08^{\mathrm{b}}$ & $1.08 \pm 0.09^{\mathrm{a}}$ & $0.75 \pm 0.08^{c}$ \\
\hline
\end{tabular}

"Ux10 $10^{2}$

Each value is mean \pm standard deviation of three individual observations.

Initial length and weight were $1.30 \pm 0.11 \mathrm{~cm}$ and $0.12 \pm 0.02$ respectively.

Mean values within the same row sharing different alphabetical letter superscripts are statistically significant at $\mathrm{P}<0.05$ (one-way ANOVA and subsequent post hoc multiple comparison with DMRT.

BI: Basal ingredients; SR: Survival rate; WG: Weight gain, SGR: Specific growth rate; FCR: Food conversion ratio; PER: Protein efficiency ratio.

Table 6. Profiles of amino acids (g/ $100 \mathrm{~g}$ dry wt.) in M. rosenbergii PL fed with diet of $75 \%$ fishmeal replaced with A. bisporus

\begin{tabular}{|c|c|c|c|}
\hline Amino acids & & Control & $\begin{array}{l}\text { Fishmeal replaced } \\
\text { diet fed PL }\end{array}$ \\
\hline \multirow{11}{*}{ EAA } & Histidine & $3.50 \pm 0.11$ & $4.62 \pm 0.04$ \\
\hline & Isoleucine & $2.85 \pm 0.08$ & $4.01 \pm 0.15$ \\
\hline & Leucine & $4.25 \pm 0.15$ & $5.03 \pm 0.08$ \\
\hline & Lysine & $2.35 \pm 0.05$ & $2.85 \pm 0.04$ \\
\hline & Methionine & $4.10 \pm 0.10$ & $4.86 \pm 0.11$ \\
\hline & Phenylalanine & $3.60 \pm 0.08$ & $4.25 \pm 0.08$ \\
\hline & Threonine & $4.69 \pm 0.13$ & $5.36 \pm 0.14$ \\
\hline & Valine & $2.87 \pm 0.06$ & $3.96 \pm 0.04$ \\
\hline & Arginine & $3.78 \pm 0.02$ & $4.90 \pm 0.08$ \\
\hline & Asparagine & $13.45 \pm 1.40$ & $13.23 \pm 1.52$ \\
\hline & Glycine & $13.25 \pm 1.12$ & $13.80 \pm 1.30$ \\
\hline \multirow{7}{*}{ NEAA } & Glutamic acid & $2.85 \pm 0.09$ & $3.01 \pm 0.04$ \\
\hline & Proline & $9.36 \pm 0.92$ & $10.02 \pm 0.72$ \\
\hline & Alanine & $3.75 \pm 0.32$ & $4.01 \pm 0.09$ \\
\hline & Tyrosine & $8.12 \pm 0.70$ & $8.08 \pm 0.62$ \\
\hline & Aspartic acid & $5.93 \pm 0.52$ & $6.56 \pm 0.90$ \\
\hline & Cystine & $3.56 \pm 0.09$ & $3.01 \pm 0.05$ \\
\hline & Glutamine & $1.96 \pm 0.06$ & $1.89 \pm 0.06$ \\
\hline \multicolumn{2}{|l|}{$\sum$ EAA } & $58.69 \pm 3.38$ & $66.87 \pm 3.94$ \\
\hline \multicolumn{2}{|l|}{$\sum \mathrm{NEAA}$} & $35.53 \pm 3.49$ & $36.58 \pm 2.48$ \\
\hline \multicolumn{2}{|l|}{$\sum \mathrm{AA}$} & $94.22 \pm 6.87$ & $103.45 \pm 6.42$ \\
\hline \multicolumn{2}{|l|}{$\sum$ EAA/NEZZ } & 1.65 & 1.83 \\
\hline
\end{tabular}

Each value is mean \pm standard deviation of three individual observations.

"Values are significant $(\mathrm{P}<0.05)$ by paired-samples' $t$ ' test.

EAA: Essential amino acid; NEAA: Nonessential amino acid; AA: Amino acid. 
Eswari S (2019) Phytochemical characterization of the mushroom Agaricus bisporus and assessment of its nutritional ability in the place of fishmeal for survival and growth of the freshwater prawn Macrobrachium rosenbergii post-larvae

the fishmeal with Chlorella vulgaris [74] and $25 \%$ fishmeal replaced with T. ornata and G. corticata [73].

\section{Profile of proteins of $75 \%$ fishmeal replaced diet fed prawns}

The general comparison between control and experiment revealed that the polypeptide bands were clearly resolved in fishmeal replaced diet fed prawns. The 119, 117, 84, 34, 28, 24 and $23 \mathrm{kDa}$ protein bands were newly appeared in the muscle of $M$. rosenbergii PL fed with $75 \%$ fishmeal replaced diet with $A$. bisporus. The 19 and $17 \mathrm{kDa}$ protein bands were deeply stained in experimental prawns when compared to that of control (Figure 6). The results observed indicated the fact that the muscle quality of $M$. rosenbergii PL has improved through incorporation of $A$. bisporus protein.

Table 7. Profiles of fatty acids in $M$. rosenbergii PL fed with $75 \%$ fishmeal replaced diet with $A$. bisporus

\begin{tabular}{|l|l|l|l|}
\hline \multicolumn{2}{|l}{ Fatty acids } & Control & $\begin{array}{l}\text { Fishmeal replaced } \\
\text { diet fed PL }\end{array}$ \\
\hline \multirow{3}{*}{ SFA } & Lauric acid (C12:0) & $0.62 \pm 0.04$ & $1.21 \pm 0.0$ \\
\cline { 2 - 4 } & Myristic acid (C14:0) & $0.49 \pm 0.03$ & $0.96 \pm 0.03$ \\
\cline { 2 - 4 } & Palmitic acid (C16:0) & $11.52 \pm 1.40$ & $14.02 \pm 0.82$ \\
\cline { 2 - 4 } & Stearic acid (C18:0) & $8.02 \pm 0.60$ & $11.08 \pm 1.21$ \\
\cline { 2 - 4 } & Arachidic acid (C20:0) & $0.65 \pm 0.05$ & $0.96 \pm 0.08$ \\
\hline \multirow{2}{*}{ MUFA } & Palmitoleic acid (C16:1) & $9.05 \pm 0.82$ & $12.96 \pm 1.45$ \\
\hline \multirow{2}{*}{ PUFA } & Olecic acid (C18:1) & $7.69 \pm 0.50$ & $12.54 \pm 0.59$ \\
\hline \multirow{2}{*}{$\sum$ FA } & Linoleic acid (C18:2 n-6) & $6.45 \pm 0.52$ & $9.04 \pm 0.95$ \\
\hline EPA (C20:5 n-3) & $0.58 \pm 0.05$ & $2.02 \pm 0.02$ \\
\hline DHFA & & $1.96 \pm 0.09$ & $2.53 \pm 0.03$ \\
\hline$\sum$ MUFA & & $49.57 \pm 4.24$ & $77.66 \pm 5.79$ \\
\hline$\sum$ PUFA & & $21.30 \pm 2.12$ & $28.23 \pm 2.20$ \\
\hline n-3 & & $16.74 \pm 1.32$ & $25.50 \pm 2.04$ \\
\hline n-6 & & $8.99 \pm 0.66$ & $13.59 \pm 1.25$ \\
\hline
\end{tabular}

Each value is mean \pm standard deviation of three individual observations.

All the values are significant $(\mathrm{P}<0.05)$ by paired-samples ' $\mathrm{t}$ ' test.

SFA: Saturated fatty acids; MUFA: Mono unsaturated fatty acids; PUFA: Poly unsaturated fatty acids; FA: Fatty acids

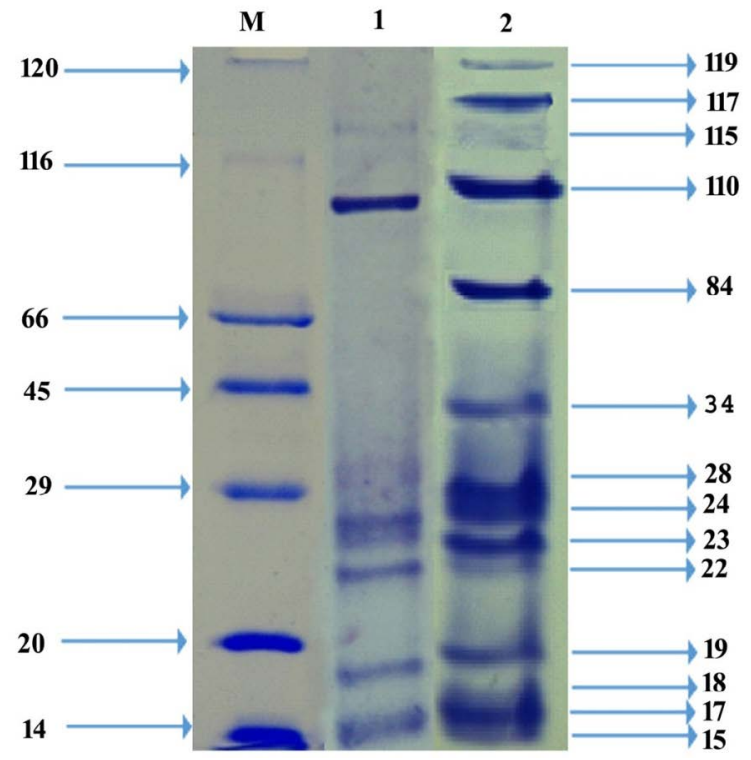

Figure 6. SDS-PAGE pattern of muscle protein of $M$. rosenbergii PL fed with $75 \%$ fishmeal replaced diet with A. bisporus (M: Marker (120: Myosin; 116: $\beta$-galactosidase; 66: Bovine serum albumin; 45: Ovalbumin; 29: Carbonic anhydrase; 20: Soyabean trypsin inhibitor; 14: Lysozyme); 1: Control; 2: Fishmeal replaced diet fed PL)

\section{Conclusion}

Fish meal is an excellent source of protein and other essential nutrients for aquaculture feed industry. Up to $75 \%$ of this has successfully and partially been replaced with A. bisporus. The recorded better growth and survival of $M$. rosenbergii $\mathrm{PL}$ by better feed conversion ratio indicated that the formulated feeds were well served and fully utilized. A. bisporus powder led to increased digestive enzymes activity, which offered better digestion, absorption and assimilation. Hence, the quality of muscle protein was improved. Thus, sustainable culture of Macrobrachium is possible.

\section{Conflict of interest}

There is no conflict of interest among authors.

\section{Acknowledgements}

The authors are gratefully acknowledged Dr. G. V. S. Murthy, Scientist 'G', Southern Regional Centre, Botanical Survey of India (BSI), Coimbatore, India, for authentication of the fungus, Agaricus bisporus. Animal Feed Analytical and Quality Assurance Laboratory (AFAQAL), Veterinary College and Research Institute, TANUVAS, Namakkal, Tamil Nadu, India, and South Indian Textile Research Association (SITRA), Coimbatore, India are acknowledged for outsourcing services provided.

\section{References}

1. FAO (2017) Aquaculture, the sustainable development goals (SDGs)/Agenda 2030 and FAO's common vision for sustainable food and agriculture. COFI sub-committee on aquaculture. Ninth session, COFI: AQ/IX/2017/5, Rome, pp: 24-27.

2. Karplus I, Hulata G, Ovadia D, Jaffe R (1992) Social control of growth in Macrobrachium rosenbergii. III. The role of claws in bull run interactions. Aquaculture 105: 281-296.

3. Mitra G, Mukhopodhay PK, Chattopadhyay DN (2005) Nutrition and feeding in freshwater prawn (Macrobrachium rosenbergii) farming. Aqua feeds: Formulation and Beyond 2: 17-19.

4. Langer S, Bakhtiyar Y, Lakhnotra R (2011) Replacement of fishmeal with locally available ingredients in diet composition of Macrobrachium dayanum. Afri $J$ Agricult Res 6: 1080-1084.

5. Kaushik SJ, Cravedi JP, Lalles JP, Sumpter J (1995) Partial or total replacement of fish meal by soybean protein on growth, protein utilization, potential estrogenic or antigenic effects, cholesterolemia and flesh quality in rainbow trout, Oncorhynchus mykiss. Aquaculture 133: 257-274

6. Goda AM, El-Haroun ER, Chowdhury K (2007) Effect of totally or partially replacing fish meal by alternative protein sources on growth of African catfish Clarias gariepinus (Burchell, 1822) reared in concrete tanks. Aquacult Res 38: 279-287.

7. Hernandez MD, Martínez FJ, Jover M, Garcia Garcia B (2007) Effects of partial replacement of fish meal by soybean meal in sharpsnout seabream (Diplodus puntazzo) diet. Aquaculture 263: 159-167.

8. Muin H, Taufek NM, Abiodum RA, Yusof HM, Razak SA (2015) Effect of partial and complete replacement of fishmeal with mushroom stalk meal and soy bean on growth performance of nile tilapia, Orechromis niloticus fingerlings. Sains Malaysiana 44: 511-516.

9. Deborah Paripuranam T, Divya VV, Ulaganathan P, Balamurugan V. Umamaheswari $S$, et al. (2011) Replacing fish meal with earthworm and mushroom meals in Practical diets of practical diets of labeo rohita and hemigrammus Caudovittatus fingerlings. Indian J Anim Res 45: 115-119.

10. Zhang D, Zhang Y, Liu BO, Jiang YI, Zhou Q, et al. (2017) Effect of replacing fish meal with fermented mushroom bran hydrolysate on the growth, digestive enzyme activity and an- tioxidant capacity of allogynogenetic crucian carp (Carassius auratus gibelio). Turk J Fish Aquat Sci.

11. Finkel T, Holbrook NK (2000) Oxidants, oxidative stress and the biology of ageing. Nature 408: 239-247.

12. Mattila P, Konko K, Eurola M, Pihlava JM, Astola J, et al. (2001) Contents of vitamins, mineral elements, and somephenolic compounds in cultivated mushrooms. J Agricul Food Chemist 49: 2343-2348. 
Eswari S (2019) Phytochemical characterization of the mushroom Agaricus bisporus and assessment of its nutritional ability in the place of fishmeal for survival and growth of the freshwater prawn Macrobrachium rosenbergii post-larvae

13. Heleno SA, Barros L, Sousa MJ, Martin A, Ferreira ICFR (2009) Study and characterization of selected nutrients in wild mushrooms from Portugal by gas chromatography and high performance liquid chromatography. Microchem J 93: 195-199.

14. Carbonero ER, Ruthes AC, Freitas CS, Utrilla P, Galvez J, et al. (2012) Chemical and biological properties of a highly branched $\beta$ - glucan from edible mushroom Pleurotussajor-caju. Carbohydrate Polymers J 90: 814-819.

15. Sajon SR, Sana S, Rana S, Mushiur Rahman SM, Mostarin Nishi Z (2018) Mushrooms: Natural factory of anti-oxidant, anti in flammatory, analgesic and nutrition. J Pharmaco Phytochem 7: 464-475.

16. Dalmo RA, Seljelid R (1995) The immune modulatory effect of LPS. Laminran and sulphated laminaran [ $\beta(1,3)$-D-glucan] on the Atlantic salmon, Salmo solar [L.] macrophages in vitrology. J Fish Diseases 18: 175-185.

17. Raa J (1996) The use of immune stimulatory substances of fish and shellfish farming. Rev Fish Sci 4: 229-288.

18. Zhang M, Cui SW, Cheung PCK, Wang Q (2007) Antitumor polysaccharides from mushroom: a review on their isolation, process, structural characteristics and anti tumour activity. Trends Food Sci Technol 18: 4-19.

19. Ullah MI, AkhtarM, Awais MM, Anwar MI, Khaliq K (2018) Evaluation of immunostimulatory and immunotherapeutic effects of tropical mushroom (Lentinus edodes) against eimeriasis in chicken. Tropical Animal Health and Production 50: $97-$ 104.

20. Shrivastava M (1998) Studies on Mushroom Dehydration (Pleurotus florida), Ph.D. Thesis submitted to IIT, KGP, W.B., India.

21. Mehta BK, Jain SK, Sharma GP, Doshi A, Jain HK (2011) Cultivation of button mushroom and its processing: an Techno-economic feasibility. Int J Adv Biotechnol Res 2: 201-207.

22. Shiuan C, Sheryl P, Gene H, Sharon K, Jingjing Y, et al. (2005) Breast cancer prevention with phytochemicals in mushrooms. Proc Amer Assoc Cancer Res 46: 5186.

23. Arianne V, Julian Renato GR, Fumio E (2018) Agro-Industrial waste conversion into medicinal mushroom cultivation. Ref Module Earth Systems Environmen Sci.

24. Winer EP, Hudis C, Burstein HJ (2002) American society of clinical oncology technology assessment of the use of aromatase inhibitors as adjuvant therapy for women with hormone receptor positive breast cancer: Status report. J Clin Oncol 20: $3317-3127$.

25. Dhamodharan G, Mirunalini S (2010). A novel medicinal characterization of Agaricus bisporus (white button mushroom). Pharmacol Online 2: 456-463.

26. Volman JJ, Mensink RP, van Griensven LJ, Plat J (2010) Effects of aglucans from Agaricus bisporus on ex vivo cytokine production by LPS and PHA-stimulated PBMCs; a placebo-controlled study in slightly hypercholesterolemic subjects. European J Clinical Nutri 64: 720-726.

27. Ozturk M, Duru ME, Kivrak S, Dogan NM, Turkoglu A, et al. (2011) In vitro Antioxidant, anticholinesterase and antimicrobial activity studies on three Agaricus species with fatty acid compositions and iron contents: A comparative study on the three most edible mushrooms. Food Chem Toxicol 49: 1353-1360.

28. Mao Y, Mao J, Meng X (2013) Extraction optimization and bioactivity of exopolysaccharides from Agaricus bisporus. Carbohydrate Polymers 92(2): 1602 1607.

29. Ghahremani-Majd H, Dashti F (2015) Chemical composition and antioxidant properties of cultivated button mushrooms (Agaricus bisporus). Horticulture Environ Biotechnol 56: 376-382.

30. Ndungutse V, Mereddy R, Sultanbawa Y (2015) Bioactive prosperities of mushroom (Agaricus bisporus) stipe extracts. J Food Processing Preservation 39: 2225-2233.

31. Smiderle FR, Ruthes AC, Van Arkel J, Chanput W, Lacomin M, et al. (2011) Polysaccharides from Agaricus bisporus and Agaricus brasiliens is show similarities in their structures and their immunomodulatory effects on human monocytic THP-1 cells. BMC Complementary and Alternative Medicine 11: 58.

32. Shao S, Hernandez M, Kramer JKG, Rinke DL, Tsao R (2010) Ergosterol profiles, fatty acid composition, and antioxidant activities of button mushrooms as affected by tissue Part and developmental stage. J Agricul Food Chem 58(22): 11616-11625.

33. Trease GE, Evans WC (1989) Pharmacology 11th Edn. Bailliere Tindall Ltd. London 60-75.

34. Vandendool H, Kratz PD (1963) A generalization of the retention index system including liner temperature programmed gas-liquid partition chromatography. $J$ Chromatogr 11: 463-467.
35. Castell JD, Tiews K (1980) Report on the EIFAC, IUNS and ICES vorking group cn standardisation of Methodology in fish nutrition research. FAO, EIFAC TECH. 36: 24

36. AOAC (1995) AOAC Official methods of analysis (16th ed). Official method 985.29: Total dietary fiber in foods-enzymatic gravimetric method, AOAC international Arlington, VA, USA.

37. APHA (2005) Standard methods for the examination of water and wastewater, 20th ed (American public health association, New York).

38. Tekinay AA, Davies SJ (2001) Dietary carbohydrate level influencing feed intake, nutrient utilization and plasma glucose concentration in the rainbow trout, Oncorhynchus mykiss. Turk J Vet Anim Sci 25: 657-666.

39. Lowry OH, Rosebrough NJ, Farr AL, Randall RJ (1951) Protein measurement with the Folin phenol reagent. $J$ Biol Chem 193: 265-275. [Crossref]

40. Moore S, Stein WH (1984) Methods in enzymol (Eds: Olowick, Spand Kalpan, ND), Academic press, New York, pp: 468.

41. Roe JH (1955) The determination of sugar in blood and spinal fluid with anthrone reagent. J Biol Chem 212: 335-343. [Crossref]

42. Folch J, Lees M, Stanely GHB (1957) A Simple method for the isolation and purification of total lipids from animal tissues. J Bios Chem 266: 497-509.

43. Barnes H, Blackstock J (1973) Estimation of lipids in marine animals and tissues. Detail investigation of the sulpho-phosphovanillin method for total lipids. $J$ Experiment Mar Biol Ecol 12: 103-118.

44. Furne M, Hidalgo MC, Lopez A, Garcia-Gallego M, Morales AE, et al. (2005) Digestive enzyme activities in Adriatic sturgeon Acipenser naccarii and rainbow trout Oncorhynchus mykiss. A comparative study. Aquaculture 250: 391-398.

45. Bernfeld P (1955) Amylases, in: Colowick SP, Kaplan NO. (Eds.), Methods in enzymology. Academic Press, New York, pp: 149-158.

46. Laemmli UK (1970) Cleavage of structural proteins during the assembly of the head of bacteriophage T4. Nature 227: 680-685. [Crossref]

47. Hess B, Sherma J (2004) Quantification of arginine in dietary supplement tablets and capsules by silica gel high performance thin-layer chromatography with visible mode densitometry. Acta Chromatogra 14: 60-69.

48. Nichols DS, Nichols PD, Mc Meekin TA (1993) Poly unsaturated fatty acids in Antarctic bacteria. Antarct Sci 5: 149-160.

49. Debnath M, Nandi M, Biswas M (2014) A critical pharmacognostic evaluation and preliminary phytochemical investigation of Alternanthera sessilis (L.) R. BR. Leaves. Indian J Pharmaceut Sci Res 4: 71-74.

50. Sivakumar R, Sunmathi D (2016) Phytochemical screening and antimicrobial activity of ethanolic leaf extract of Alternanthera sessilis (L.) R. BR. EX DC and Alternanthera philoxeroides (MART.) Griseb. Europ J pharmaceut 3: 409-412.

51. Bhushan MS, Rao CHV, Ojha SK, Vijayakumar M, Verma A (2010) An analytical review of plants for anti diabetic activity with their phytoconstituents and mechanism of action. Int J Pharmaceut Sci Res 1: 29-46.

52. Latha M, Pari L (2003) Anti hyperglycemic effect of Cassia auriculata in experimental diabetes and its effect on key metabolic enzymes in carbohydrate metabolism. Clin Experimen Pharmacol Physiol 30: 38-43.

53. Kalaiselvi VC, Saravana Bhavan P, Kalpana R, Rajkumar G, Satgurunathan T (2018) Phyllanthus amarus enriched Artemia nauplii enhanced survival, growth and nutritional quality of early post-larvae of the prawn Macrobrachium rosenbergii. Clin Nutr Metab 1: 1-15

54. Prabhadevi V, SathishSahaya S, Johnson M, Venkatramani B, Janakiramana N (2012) Phytochemical studies on Allamanda cathartica L. using GC-MS. Asian Pacific $J$ Tropical Biomedicine 2: S550-S554.

55. Markkas N, Govindharajalu M (2015) Determination of phytocomponents in the methanolic extract of Mollugo cerviana by GC-MS analysis. Int J Res Biol Sci 5: 26-29.

56. Sivakumar MVK, Motha R, Wilhite D, Qu J (2011) Towards a compendium on national drought policy: Proceedings of an expert meeting. American meteorological society.

57. Diana HY, Parthipan BN (2015) Compounds identification from hypersaline Oscillatoria Salina using GC-MS Analysis. Int J Res Stud Biosci 3: 6-10.

58. Priya EP, Subhashini S (2016) Thin layer and deep bed drying basic theories and modeling. Agric Eng Int 18: 314-325.

59. Hassan MM, Oyewale AO, Amupitan JO, Abduallahi MS, Okonkwo EM (2004) Preliminary phytochemical and antibacterial investigation of crude extracts of the root bark of Detarium microcarpum. J Chem Soci Nigeria 29: 26-29. 
Eswari S (2019) Phytochemical characterization of the mushroom Agaricus bisporus and assessment of its nutritional ability in the place of fishmeal for survival and growth of the freshwater prawn Macrobrachium rosenbergii post-larvae

60. Kumar A, Mazzanti M, Mistrik M, Kosar M, Beznoussenko GV, et al. (2014) ATR mediates a checkpoint at the nuclear envelope in response to mechanical stress. Cell 158: 633-646. [Crossref]

61. Chandrasekaran S, Gaurav G, Serino S, Miranda (2011) Ringing and springing response of triangular TLPs. International Shipbuilding Progress 58: 141-163.

62. Venkata Raman B, Samuel LA, Pardha Saradhi M, Narashimha Rao B, Vamsi Krishna AN, et al. (2012) Antibacterial, Antioxidant Activity and GC-MS Analysis of Eupatorium odoratum. Asian J Pharmaceut Clini Res 5: 99-106

63. Sudha T, Chidambarampillai S, Mohan VR (2013) GC-MS Analysis of bioactive components of aerial parts of Fluggea leucopyrus Willd (Euphorbiaceae). J Appl Pharmaceut Sci 3: 126-130.

64. Yu Y, Lee C, Kim J, Hwang S (2005) Group-specific primer and probe sets to detect methanogenic communities using quantitative real-time polymerase chain reaction. Biotechnology Bioengineering 89: 670-679

65. Swamy DN (1995) Traning manual, short-term course in Biotechnological approaches in prawns and fish Nutrition and Feed Technology. CIBA, Madras 82-88.

66. Gimenez Ana F, Díaz Ana C, DíazSusana C, Susana V, Jorge L, et al. (2009) Partial substitution of fishmeal by meat and bone meal, soybean meal, and squid concentrate in Feeds for the prawn Artemesia longinaris: Effect on digestive proteinase. Isr J Aquac 61: 48-56.

67. Mukhopadhyay PK, Rangacharyulu PV, Mitra G, Jana BB (2003) Applied nutrition in freshwater prawn, Macrobrachium rosenbergii culture. J Appl Aquacult 13: 317-340.
68. Aarumugam P, Bhavan PS, Muralisankar T, Manickam N, Srinivasan V, et al. (2013) Growth of Macrobrachium rosenbergii fed with mango seed kernel, banana peel and papaya peel incorporated feeds. Int J App Biol Pharm Tech 4: 12-25.

69. Fang LS, Tang CK, Lee DL, Chen IM (1992) Free amino acid composition in muscle and hemolymph of the prawn Penaeus monodon in different salinities. Nippon Suisan Gakk 58: 1095-1102.

70. Wilson RP (2002) Amino acids and protein. In: Halver JE, Hardy RW (Eds.), Fish Nutrition. Academic press, San Diego. CA, USA, pp: 143-179.

71. Emelyanova LV, Koroleva EM, Savina MV (2004) Glucose and free amino acids in the blood of lampreys (Lampetra fluviatilis L.) and frog (Ranatemporaria L.) under prolonged starvation. Comp Biochem Physiol Part A Mol Integr Physiol 138: 527-532.

72. Bhavan PS, Radhakrishnan S, SeenivasanC, Shanthi R, Poongodi R, et al. (2010) Proximate composition and profiles of amino acids and fatty acids in the muscle of adul males and females of commercially viable prawn species Macrobrachium rosenbergii collected from natural culture environments. Int J Biol 2: 107-119.

73. Rajkumar G, Saravana Bhavan P, Srinivasan V, Udayasuriyan R, Karthik M, et al (2017) Partial replacement of fishmeal with marine algae Turbinaria ornata and Gracilaria corticata for sustainable culture of the freshwater prawn Macrobrachium rosenbergii. Int J Res Stud Zool 3: 32-44.

74. Radhakrishnan S, Bhavan PS, Seenivasan C, Muralisankar T (2015) Effect of dietary replacement of fishmeal with Chlorella vulgaris on growth performance, energy utilization and digestive enzymes in Macrobrachium rosenbergii post larvae. Int J Fish Aqua 7: 62-70.

Copyright: (C2019 Eswari S. This is an open-access article distributed under the terms of the Creative Commons Attribution License, which permits unrestricted use, distribution, and reproduction in any medium, provided the original author and source are credited. 